\title{
Activity Theory as a lens to examine pre-service Teachers' perceptions of learning and teaching of Mathematics within an intervention programme
}

\section{Subethra Pather}

To cite this article: Subethra Pather (2012) Activity Theory as a lens to examine pre-service Teachers' perceptions of learning and teaching of Mathematics within an intervention programme, African Journal of Research in Mathematics, Science and Technology Education, 16:2, 253-267, DOI: $10.1080 / 10288457.2012 .10740743$

To link to this article: https://doi.org/10.1080/10288457.2012.10740743

\section{曲 Published online: 20 Aug 2013.}

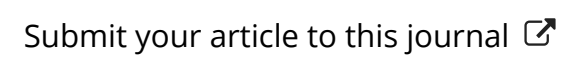

山 Article views: 59

Citing articles: 1 View citing articles $\longleftarrow$ 


\title{
Activity Theory as a lens to examine pre-service teachers' perceptions of learning and teaching of Mathematics within an intervention programme
}

\author{
Subethra Pather \\ Faculty of Education \& Social Science, Cape Peninsula University of Technology, \\ South Africa pathersu@cput.ac.za
}

\begin{abstract}
:
This study was prompted by concerns around mathematics teaching and learning in the South African education system. Contributory factors to this situation are the lack of competent mathematics teachers in the classroom and mathematics at-risk students entering teacher education programmes. This paper reports on how a mathematics intervention programme (MIP) assisted in shaping at-risk student teachers' perceptions of their learning and teaching of mathematics. Activity Theory (AT) is used as a theoretical lens for examining these students' perceptions. Qualitative data were collected using in-depth interviews with 12 students and their written and graphical reflections of their experiences in the MIP. The results confirm that the students' perceptions of their learning and teaching of mathematics had changed. Furthermore the study provides evidence that strategically planned interventions to deal with historically imbalances can and do work. The study concludes that the MIP had a positive effect on the students with regard to improving their attitudes and level of confidence in learning and teaching mathematics.
\end{abstract}

Keywords: Activity theory, at-risk student teachers, learning \& teaching of mathematics.

\section{Introduction}

Even though South Africa is now seventeen years into post-apartheid transformation, there are still a large number of students who enter higher education with a lack of academic preparedness (Scott, Yeld \& Hendry, 2007). As a result, many of these students are at-risk ${ }^{1}$ of failing or dropping out of university due to their poor grounding within the South African school system.

This research arose as a response to a lack of academic preparedness in mathematics amongst first year students, who registered for the B Ed degree at a University of Technology in South Africa. Anecdotal evidence (past mathematics tests and assignment results) indicates that some of these first year students' mathematic performance is of great concern. The Third International Mathematics and Science Study (TIMSS) in 1995 and a later TIMSS -R in 2003 reveal that South African secondary school learners have achieved significantly below the international benchmark (Reddy, 2006). Reddy concludes that some of the contributory factors to the poor mathematics performance are the lack of adequately qualified mathematics school teachers, overcrowded classrooms and lack of resources.

1 In this study at risk is understood to be a student who risks academic failure because his or her skills, knowledge, motivation and academic abilities are significantly below that of a typical student (Maxwell, 1997). 
A study of the 2003-5 EMIS data reveals that three times as many teachers teach mathematics than the number of teachers that have specialised in mathematics in their teaching qualification (Arends, 2008). An unfortunate consequence of such large numbers of unqualified mathematics teachers is that many high school graduates enter teacher education programmes with a poor grasp of mathematical concepts and, in some cases, an associated dislike for the subject. Although these students are exposed to mathematics education at teacher education institutions, many of them graduate and return to the classroom, without having overcome their lack of proficiency in mathematics (Arends, 2008).

The challenge currently facing mathematics education lecturers is how to break the vicious cycle of under-achieving student teachers (from now on called students) becoming ill-prepared teachers of mathematics. One approach to address this challenge would entail intervention strategies to improve students' subject and pedagogical knowledge. These interventions will also help to reduce attrition and the number of under-prepared students (Howells, 2003). However, when devising effective intervention programmes it is crucial that the first year teacher education students' school-based learning experiences be taken into account. The students' mathematical experiences such as, low achievement, repeated failure, low confidence and negative perceptions of learning mathematics during their formative years in the classroom, have shown to have a major impact on their performance as teachers (Eaton and Kidd, 2005).

It is in this broad context that the research problem of this study is located. Specifically the study investigated how a mathematics intervention programme (MIP) was able to shape the students' perceptions of their learning and teaching of mathematics. The following research question lent focus to the study:

What aspects of the Mathematics Intervention Programme shaped at-risk student teachers' perceptions of their learning and teaching of mathematics?

\section{Activity Theory as a theoretical framework}

Several studies in the extant literature were considered during the research design of this study. Relevant models, frameworks and theories were weighed against the elements of the research problem and subsequently Engeström's (1987) activity theory (AT) was identified. The study is thus contextualized within the AT framework (Figure 1) which is composed of interacting components: subject, tools, object, division of labour, community and rules.

Activity theory was originally derived from the work of Vygotsky (1986) and Leont'ev (1978) and later expanded upon by Engeström (1987). This framework, which was used as a lens to analyse the data in this study, portrays the inter-relationships between the subject, object, and mediating tools, which is set in the social context of rules, community and division of labour. The value of using AT as a lens is clarified when one examines the core of the MIP, explores different facets of the programme, and obtains insight into aspects of how the MIP environment contributed to the at-risk students' perceptions of learning and teaching mathematics. It also allowed the investigation to dissect the MIP across the six components and to examine the relationships between the components. 


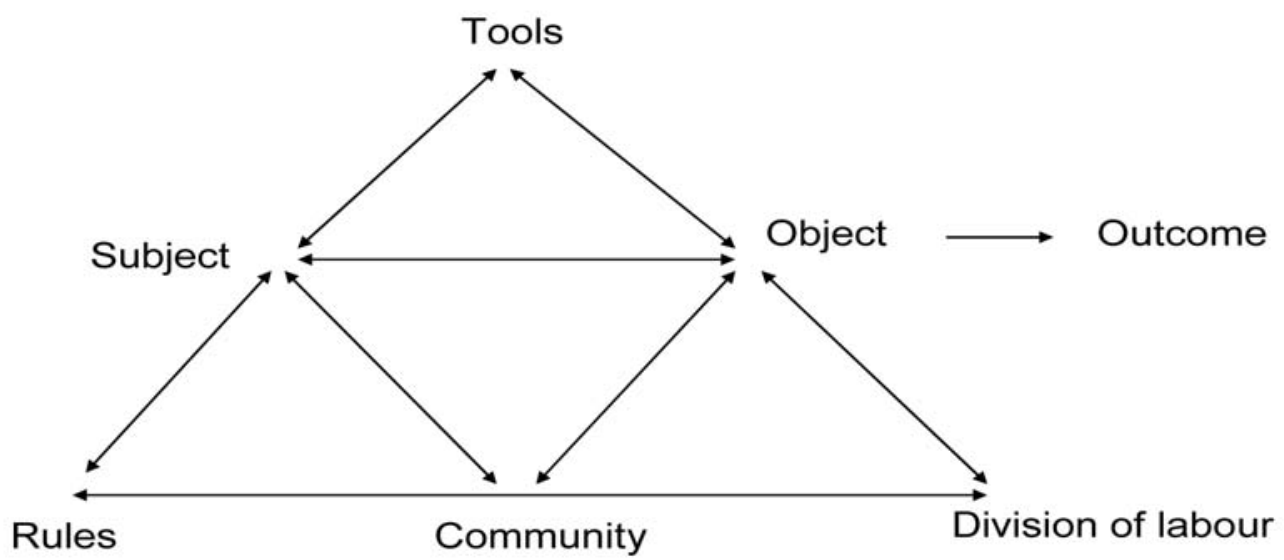

Figure 1: The basic triangular model of AT (Engeström,1987, p78)

According to Engeström (1987) the analysis is conducted from the point of view of the subject forming the focus of the action. The subject uses mediated tools to reach the object. Kuutti (1996) asserts that a tool can be anything used in the transformation process, including material aids and techniques for thinking. Tools alter the activity and are in turn altered by the activity. The object is the central issue to which the activity is directed and eventually leads to an outcome as a consequence of the activity. Engeström (1987) notes, that the rules component should refer to the explicit and implicit regulations, norms and conventions that constrain actions and interactions within the activity system. These define how subjects must fit into the community. The community comprises multiple individuals who share the same overall object and who construct themselves as distinct from other communities. The community component therefore includes the notion that an activity is carried out within a social and cultural context or within the environment in which the subjects operate. The division of labour or roles describes how the object of the activity relates to the community and refers to both the horizontal division of tasks between its members and the vertical division of power and status.

The unit of analysis in AT is the activity system. Russel (2002: 67) defines the activity system as a flexible unit of analysis (theoretical lens) that allows the researchers to train their gaze in different directions and with different levels of magnification to help them answer the questions that puzzle them.

Some researchers argue that there are still many unsolved issues related to AT especially with regard to the nature and role of transformation in activity systems and the relation of collective and individual activity (Roth, 2004; Daydov, 1999). Hardman (2005) adds that AT is used primarily as an interventionist tool and there are only a few analyses that deal with its use in exploratory studies. However, AT has been applied within diverse disciplinary settings, e.g. in product design, studies in creativity, drama, and in education. 


\section{Case Study: A Mathematics Intervention Programme at a teacher educa- tion institution}

In an attempt to address the concerns of poor mathematics performance and an aversion for the subject, a MIP was implemented in the B Ed programme in the Faculty of Education at a University of Technology. Four important factors, specifically related to the B Ed, General Education and Training (GET: Grade R to 8) programme that underpinned the implementation of the MIP were:

i. Mathematics and Numeracy forming a fundamental part of the primary school curriculum (Grade R to 8);

ii. The incoming students' low level of preparation for the introductory mathematics course;

iii. The rapid increase in student intake and the concomitant increasing diversity of students' academic backgrounds and profiles; and

iv. The high drop-out rate at first year level.

The design of the MIP targeted students who were at-risk of failing the first year Introduction to Mathematics course. The following criteria were used to identify at-risk students:

v. Failed Grade 12 mathematics or Grade 9 is the highest mathematics qualification;

vi. Failed the mathematics diagnostic test administered by the Faculty at the beginning of the academic year; and

vii. Adult students returned to study after a long period of absence, with or without Grade 12 mathematics.

The at-risk students were invited to join the MIP class which was held in parallel sessions to the mainstream introductory group. An additional forty-five minute class per week was allocated to the MIP to accommodate the slower pace of teaching and learning. This afforded the students the opportunity to ask questions and seek assistance from peers and the lecturer.

A second strategy underpinning the MIP was the smaller class size that averaged twelve students. The five MIP groups were taught by a qualified mathematics specialist who has had many years of experience in teaching at-risk students.

The tenet of the $\mathrm{OBE}^{2}$ approach to teaching was taken into account by the designers of the MIP. Key design features of the new OBE strategy to teaching are learner-centredness, collaborative learning and the lecturer's role as facilitator. This technique commences with a clear picture of what is important for students to be able to do, then organizing the curriculum, instruction, and assessment to ensure that learning objectives are achieved (Spady, 1994). This implies that

2 Outcomes-based Education (OBE) was introduced by the South African Government of National Unity in 1997 and implemented in 1998 as a curriculum reform intended to "democratise education and eliminate inequalities" of the old education system (Jansen, 1998: 1-2). 
the students are actively involved in their learning to reach new understanding. The students' experience of classroom practice is therefore an important dimension. Cooper (2007) suggests that outcomes-based teaching is closely aligned to the social constructivist school which is characterised by the use of prior knowledge for new learning; active involvement in the learning process and knowledge which is continually changing. Social constructivist literature on learning interventions that was reviewed for the design of the MIP were from Vygotsky (1978), Wertsch (1997), Kukla (2000), and Van Meter and Stevens (2000).

\section{Research method}

The principal research strategy adopted was that of case-study research. An interpretivist approach and qualitative data collection techniques were deployed in this study. Purposeful sampling was used to select 12 participants from the 60 MIP students, based on prior identified criteria for inclusion (Wiersman \& Jurs, 2005). All students were divided into two groups: students with Grade 12 mathematics and those without. For each group students were ranked according to their diagnostic test results, and two each were selected from the categories- the high, low and median scores. Semi-structured interviews were conducted with the 12 participants providing the primary data source. Prepared interview schedules were used to guide the interview consisting of questions that were divided according to the six components of the AT system. However, in formulating the questions attention was not drawn to the six components explicitly. Picture cards were also used in the interview. The categories that were outlined in each picture card were: improved results; collaboration; attitude to learn mathematics; confidence to learn mathematics; attitude to teach mathematics; confidence to teach mathematics; and learning of mathematics concepts. In this activity the student had to arrange the picture cards from the one that made the most significant impact to the least impact on their mathematics learning and teaching. They could also leave out cards. The objective of the sort-card activity was to glean the maximum information from the respondents. According to Nurmuliani, Zowghi and Williams (2004) card-sorting is a knowledge elicitation method that is used to capture information about different ways of representing domain knowledge.

The primary data source provided the means to understand the change in mindsets of the participants. These data were supplemented with students' illustrative and written reflections of their mathematics experiences which were captured during a separate exercise. NVivo (a qualitative data analysis software tool) was used to facilitate the process of content analysis. This involved identifying, coding, categorising, classifying and labelling the primary patterns in the data, and then mapping these onto an expanded activity system, viz., an AT model.

The findings were based on analysing students' perceptions of their learning and teaching of mathematics within the MIP and presented within an AT framework. In this study the activity was defined as the students' learning and teaching of mathematics within the MIP learning environment. The upper part of the AT triangle includes the subject (the student teacher), object (the subjects' demonstrated teaching and learning knowledge of mathematics) and mediated tools (various learning and teaching techniques employed by the MIP). This top triangle was used to examine how the students used mediated tools to understand their learning and teaching of mathematics. The base of the triangle includes rules (the explicit and implicit MIP classroom rules), community (lecturer and students) and division of labour (the MIP community). These aspects were used to examine how the social environment within the MIP classroom influenced the students' perceptions of learning and teaching mathematics. 
Activity Theory facilitated a holistic interrogation of the students' learning and teaching of mathematics within the social setting of the MIP classroom. In addition, it magnified each component to be examined individually and with equal attention which enabled an exploration of the relationships among the six components of the AT system as they pertained to the research problem (as indicated in the findings section). This process produced both rich and sufficiently detailed data with respect of the research question and enhanced the quality of the study through ensuring the credibility and dependability of the findings.

\section{Research findings}

The findings regarding each of the six components are reported individually.

\section{Subject: student teacher}

The subjects' demographic information and interview excerpts about their prior school-based mathematical learning experiences provided an important background (refer Table 1). Firstly, the ages of the students ranged from 19 years to 40 years. Sixty seven percent of the students in the study had returned to the university after an extended period of absence. This meant that many of them were not familiar with the OBE approach to learning mathematics. Secondly, a majority of the subjects did not have the basic mathematical grounding needed for the B Ed first year mathematics course. Column three and four in Table 1 indicate that three quarters of the students were last exposed to mathematics from 4 to 19 years prior to university entry. One of the interviewees' comments typifies the nature of their school-based experience with mathematics:

\section{"I finished school in 1992, I last did maths when I was in standard 7 so that was 19 years ago.......".}

From column four it is noted that more than half of the participants were not English first language students. When questioned about the impact of learning mathematics through the medium of English in the MIP, all participants indicated that the medium of instruction was not a debilitative factor to their learning of mathematics. In contrast, column five reveals that the majority of the students had entered the MIP with a negative attitude and a fear of learning mathematics as a result of their prior mathematics experiences. This synopsis of students' prior experiences and their particular needs informed the learning environment of the MIP. The diversity of their ages; their weak foundations in mathematics; long period of absence from a formal mathematics learning environment; negative attitudes and anxiety were important considerations in analyzing and understanding how the students used the mediated tools in the MIP environment to achieve the set objectives. The discussions of the findings that follow, therefore take into account this profile of the student. 
Table 1: Demographics of the sample of respondents showing previous mathematics experience 3

\begin{tabular}{|c|c|c|c|c|}
\hline $\begin{array}{l}\text { Student } \\
\text { teacher }\end{array}$ & Age & $\begin{array}{c}\text { Highest } \\
\text { mathematics } \\
\text { qualification }\end{array}$ & $\begin{array}{c}\text { First } \\
\text { Language }\end{array}$ & $\begin{array}{c}\text { Excerpt from interview indicating student } \\
\text { teachers' prior mathematical learning } \\
\text { experiences }\end{array}$ \\
\hline $\mathbf{N}$ tobi & 40 & Grade 9 & Xhosa & $\begin{array}{l}\text { "Had a bad maths teacher h school. Scared of failing maths in } \\
\text { grade } 12 \text { therefore did not take \& beyond Grade } 9 \text {. }\end{array}$ \\
\hline Thabi & 30 & Grade 9 & Xhosa & $\begin{array}{l}\text { "Did not have a teacherthat was senious about maths. He never } \\
\text { checked homework or attendance". }\end{array}$ \\
\hline Olive & 29 & Grade 9 & Afrikaans & $\begin{array}{l}\text { "Was afraid of doing maths. Sat in the back of the class so that I } \\
\text { would not be noticed". }\end{array}$ \\
\hline Morgan & 22 & Grade 9 & English & "Was in a religious school. Was tau'ght to memorize work". \\
\hline Mandy & 20 & Grade 9 & English & "I was scared of dong mathematics, I did not know how to do $\mathrm{R}$ " \\
\hline Sandy & 19 & Grade 9 & English & $\begin{array}{l}\text { "Did not have a good maths teacher at school Teacher was not } \\
\text { creative in the lesson". }\end{array}$ \\
\hline Vosi & 29 & Grade 12 (SG) & Xhosa & $\begin{array}{l}\text { "Not confidence in maths. Failed Grade } 12 \text { maths due to lack of } \\
\text { confidence and working on my own" }\end{array}$ \\
\hline Fran & 25 & Grade 12 (SG) & English & $\begin{array}{l}\text { "Maths teacher wes very good but could not teach the subjed well. } \\
\text { We mainy used the text book and worked out examples". }\end{array}$ \\
\hline Nora & 24 & Grade 12 (SG) & Xhosa & $\begin{array}{l}\text { "The teacher taught maths in the traditional way, we had to work } \\
\text { on our own": }\end{array}$ \\
\hline Jane & 22 & Grade 12 (SG) & Afrikaans & $\begin{array}{l}\text { "Had a very advanced maths teacher, scared me, I developed } \\
\text { maths anxiety and therefore did badh in my maths exams". }\end{array}$ \\
\hline Xhosi & 21 & Grade 12 (SG) & Xhosa & $\begin{array}{l}\text { "Had a very knowledge able maths teacher at school but she was } \\
\text { unable to teach maths effoctiven" }\end{array}$ \\
\hline Mira & 20 & Grade 12 (SG) & English & $\begin{array}{l}\text { "My maths teacherwas the Deputy Principal he was rarely in } \\
\text { class. Did not spend time with indwiduals tudents as higher and } \\
\text { standard grade students were taught together". }\end{array}$ \\
\hline
\end{tabular}

\section{Tools: Teaching and learning strategies}

The teaching and learning strategies used in the MIP were adopted specifically for the needs of the students in the MIP class. The strategies were intended to reduce mathematics anxiety, build confidence and improve performance and understanding of learning and teaching mathematics.

Firstly, from the interviews it emerged that students did not consider familiar learning and teaching strategies as mediating tools, for example, homework, the use of the overhead projector and question and answer techniques. Strategies that were new to them or had an impact on their learning and teaching of mathematics were perceived as mediating tools, for example, the use of worksheets, using/ making of objects, group work, plenty of examples, repetition and probing. A combination of these techniques used for teaching concepts allowed the students to complete the task with minimum frustration or anxiety and to reach levels of performance that they had previously felt were unachievable. The following interview excerpt substantiated the above finding:

3 Note that in keeping with confidentiality agreements with the research subjects, actual names have been replaced with pseudonyms. 
Activity Theory as a lens to examine pre-service teachers' perceptions of learning and teaching of Mathematics within an intervention programme

The lecturer always used different methods, she will explain something to you then she will use the board and put some examples, etc and you must work it out. Then the lecturer will walk around and if you have a problem you can ask her. She's a person who will help you. You just raise your hand and she will assist.

The students were not only able to see the benefits of selected techniques for enhancing their own learning of mathematical concepts, but also in their teaching of mathematics. The following quote corroborates that students felt comfortable in modelling their lecturer's strategies:

You know, I was teaching maths when we were at teaching practice I really enjoyed myself I actually applied the same technique that the lecturer was doing without even knowing. I wasn't only teaching a sum on the board, but I will always ask, and I see it worked. I always ask the learners 'what do you think?' and I put them in groups and stuff. It helped me, I applied that and that works for me.

This was an important observation, since it is indicative of the transference of the learning from the MIP into the external school environment.

A second strategy that appeared to be very successful was the small class size. All the students interviewed acknowledged that the small class size was effective in their learning and teaching of mathematics. The following extract corroborates this:

In the small class, she had time to go around and when someone was stuck she would attend to them. Also everyone gets a chance to give an opinion or an answer so we built a lot of selfconfidence in the class. I liked the small classes and the attention.

A third effective strategy was the slower pace of lessons. Sixty-six percent of the subjects appreciated the relaxed pace in which the lessons were conducted and regarded this as beneficial to their own learning. From the small percentage of $34 \%$ that did not particularly approve of the slower pace of work, half of them used this time to teach their peers and also work out additional examples. This advanced their teaching and learning of mathematics. However, the remaining $50 \%$ expressed boredom and noted at times that they felt tempted not to attend class. This result underscores the importance of the learning environment being individualised.

\section{The Community: MIP classroom environment}

The findings in this section focus on the MIP classroom, peers/students and the lecturer and discuss the activity of the students within the social context of the MIP environment in which they operated.

\section{The MIP classroom}

The layout of the MIP classroom was different from the traditional university classrooms. Desks and chairs were arranged in groups. This created adequate space for movement in the classroom, allowing the students to interact with one another, work in groups or individually. The flexibility in the physical arrangement also enabled the lecturer to interact with the class with greater ease and had a positive influence on the students as indicated below: 
The layout of the desks made it easy to move around, it made us feel comfortable; we could sit anywhere we wanted to sit as long as we're comfortable and can see her properly.

In addition, the MIP classroom had a relaxed atmosphere. The ambience enabled greater interaction between students and lecturer. The lecturer was able to provide individualised tuition thereby encouraging students to use a diverse range of methods to solve problems.

The students acknowledged that they felt safer in the MIP classroom as compared to their other lecture venues and this security encouraged and offered them a better scope to explore innovations and undertake a trial of a wider range of strategies when responding to mathematical problems. This was highlighted in the following excerpt:

There wasn't a lack of participation in the class........everyone felt comfortable and confident enough to participate; people understood in this class we're not here because we're brighter or dumber than anyone else. There was no such thing as a stupid question.... if you didn't understand you knew that you could just ask any question and the lecturer would go through it or someone would go through it with you.

Other responses by the students revealed that their work and comments in the MIP classroom were valued and respected. They also established that this classroom was a non-judgmental environment which allowed and encouraged them to take risks without the fear of being 'laughed at', or becoming despondent with comments such as 'wrong' or 'stupid'. One of the respondents added:

As we were a smaller group and no one looked down on you, so it's easy to say you don't understand and the lecturer will help you. We were all very interactive and confident. We weren't shy or scared to make a mistake.

The MIP classroom, inter alia, was contributory to the reduction of the students' mathematics anxieties and it increased their willingness to attempt solving difficult mathematics problems.

\section{The Peers/Students}

All the students in the MIP had an important role, in that they facilitated the social interaction in the community. The students were involved in activities that concerned exploring, co-operating, sharing and reflecting with one another. Such involvement brought about a sense of security, self confidence and a reduction in anxiety for many of the students, as indicated in the previous section. The following remark speaks of the 'enjoyment' that was obtained from group interaction:

Yes all of us enjoyed it. There was interaction between us.... we could learn from each other.....if you know something you can tell me and we can help each other. We work well together and we have learnt a lot about someone's interpretation, it's not the same as yours, so you get a broader understanding.

In addition, many of the students felt comfortable to work on their own in solving mathematics problems, but were always willing to assist others.

Finally, the safe and comfortable learning environment, together with the supportive role played by the MIP community, constructed an environment that was different from other learning communities. It was unique in that the students were aware of each other's weak mathematics foundation, they felt they were all in the same 'boat' and needed to support and encourage one 
another. This allowed the students to be open and honest about their mathematical shortcomings which made collaborative work more effective. This also allowed the students to carry out their activity in a supportive and caring environment in which the MIP operated.

\section{The rules}

Some of the rules that mediated the relationship between the students and the lecturer were constructed solely by the lecturer. The following excerpt points out the explicit rules identified by the lecturer:

They had to do homework every single time...100\% attendance and $100 \%$ participation.......in the lessons and .... ask questions...if there was anything going on that they don 't understand they needed to ask.... I did different things all the time but the rule was always that they could ask a friend.... when they were struggling or could sit with somebody.

Students identified the following as explicit rules: "...we had to write tests, a lot of spot tests", "...we had to do homework... and then she gave us 10 marks", "she will put examples on the board and you must work it out", "...we had to attend every class and we had to ask questions if we did not understand". Some implicit rules were noted during the interview: "...you must raise your hand and she will be there....", "...everyone gets a chance to give an opinion or answer...", "the MIP class was informal yet the lecturer wouldn't let it get out of hand" It was interesting to note that students identified explicit rules mainly related to assessment and quantified as marks. In contrast, the implicit rules were seen as embedded within the structure of the lesson.

\section{The division of labour}

Members of the community undertook different roles. The use of the varying teaching and learning strategies allowed for the changing roles of the lecturer and students, and for social interactions and shared responsibility for the students' learning and teaching of mathematics.

At times the lecturer undertook many roles, ranging from facilitator, motivator, modeller, coordinator, teacher and expert. The students used the following descriptors when asked to identify the role of the lecturer in the MIP classroom, viz., teacher, supporter, empathizer, advisor, and motivator. There were also times when the roles were reversed. In many of their group activities, students acted as the facilitator, motivator, modeller, coordinator, and expert in assisting one another.

A role that was not explicitly identified by students was the role of the lecturer as administrator, examiner and assessor.

\section{The object}

The main intention of the MIP was to enhance the students' learning and teaching knowledge of mathematics. Students' responses from the picture cards activity formed an integral part of the evidence of their overall perception of the intervention programme.

The first significant observation from the picture card activity was that all the students acknowledged that the MIP had definitely improved their performance in mathematics as indicated by the following respondent: 
Oh yes, my marks improved gradually but definitely......not to the best of the best but I saw an improvement after each test, after the MIP classes.

Secondly, $75 \%$ of the students felt collaborative learning was more effective than individual work. This strategy was new for many of the students as it was not used very often in their mathematics learning at school, as illustrated below:

I found that working with groups was something new for me. I didn't do that before so I engaged myself with the group and that had made my understanding of mathematical concepts more easier for me. I became more comfortable with mathematics and really enjoyed group work.

Thirdly, $67 \%$ and $60 \%$ respectively of the sample acknowledged an increase in their confidence in, and attitude towards, learning mathematics. The improved mathematics grades and the students' ability to successfully completing mathematical tasks created a shift in their perception of learning the subject. As an example, one respondent acknowledges:

"I don't think I'm scared of maths anymore ..... I find maths exciting ....... at high school maths used to be a chore ....... like washing the floors but now it's far more exciting ....... I am a little bit more confident and have a little bit more tools to tackle it with.

This shift had also resulted in the student teachers being more motivated to learn mathematics. As one respondent stated:

I was always afraid to do maths. I thought I was stupid and I don't understand maths being in the MIP class has made me understand mathematics I feel comfortable doing maths. Now I'm definitely motivated to learn maths.

However, in contrast to the students' confidence and motivation to learn mathematics, the results show a lower confidence and attitude to teach mathematics. The students felt that they were not ready to teach mathematics even though their mathematics marks had improved. A respondent stated:

I don't have confidence in teaching maths...... when you teach you must expect some questions you must be able to answer those questions and people will come up with different questions and need different answers; so you must be prepared....... I'm still nervous to teach maths.

Finally, the picture cards activity revealed that only a small percentage of the students acknowledged that their method of learning mathematics has changed. The majority said that they "still stick to the learning method that I used at school".

Many of the students acknowledged they did not give any thought to their method of learning mathematics. This could indicate that the students did not fully understand what was expected of them when commenting on that particular sort card.

\section{Discussion of findings}

The findings indicated that both the top of the AT triangle (tools) and its base (rules, community and division of labour) have contributed to a positive outcome in students' perceptions of their learning and teaching of mathematics knowledge. These aspects of the MIP learning environment can be summarised as an innovative design of the classroom environment and the selected teaching and learning strategies used in the MIP. 
Importantly, the classroom environment and the strategies used were not independent contributors to the positive outcomes. Rather it was the ongoing interaction between the elements of the classroom environment and specific teaching and learning strategies applied in the MIP, which jointly contributed to a change in perception amongst the subjects as reflected in Figure 3.

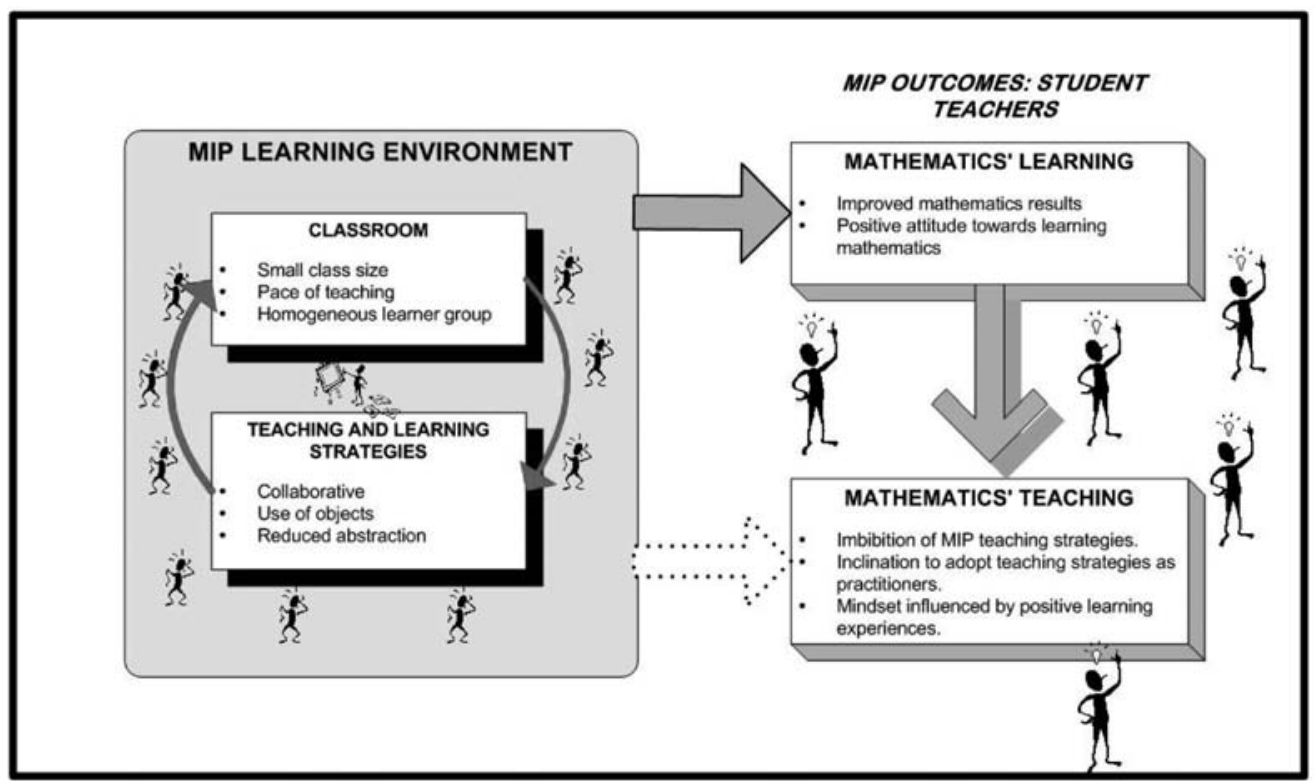

Figure 2: Overview: MIP influence on students' learning \& teaching of mathematics

\section{MIP: Classroom environment}

A key theme which emerged throughout the interviews was the enhancing role of the MIP classroom environment, as shown in Figure 3. Aspects of this were emphasized by all interviewees. The small class size, the slower pace of learning and teaching, and the homogeneous learner group collectively provided uniqueness to the environment. A second issue highlighted the characteristics of the MIP classroom environment as being non-threatening and comfortable. This resulted in the students' sense of confidence to seek help from the lecturer and other students, to try out new ways of solving mathematical problems, to voice their opinions and discuss mathematical issues with the lecturer and peers.

\section{MIP: Learning and teaching strategies}

The various learning and teaching strategies used in the MIP class built on the students' knowledge of learning and teaching mathematics, and assisted the group with their varied learning needs. This teaching strategy played a critical role in fostering a change in the students' perceptions of learning mathematics. A key issue in the findings points to the MIP learning and teaching strategies as a way of guiding students towards an interactive and social constructivist approach to their learning activities. This enhanced a self-awareness of the students' own cognitive abilities which they then applied to the tasks in the MIP. However, the various strategies used in 
the MIP did not have the same impact on all students. Two distinct results that can be deduced from the tool-mediated activity were firstly, that all the students were positive in acknowledging their improved mathematics achievement. However, the majority did not consider that they changed their methods of learning in order to obtain these improved results. Secondly, the findings indicate that the teaching and learning strategies considered effective for students' own learning of mathematics were also recognised as those that they would be inclined to adopt when teaching mathematics.

\section{Students 'perceptions of learning and teaching mathematics}

Figure 3 highlights the distinction between the students' perceptions of learning mathematics and the way they perceived the teaching of the subject. The findings indicated that the following factors contributed to the students' ability to perceive the learning of mathematics in a positive light: small class size; lecturer's attitude; varied teaching and learning techniques; individual attention; peer support; and visible improvement in their mathematics results.

The evidence revealed that the majority of the MIP students entered the programme with a negative attitude and a fear of learning mathematics. The importance of both the constructivist teaching and learning strategies and the learning experiences of the students in the MIP contributed to the positive shift in their perceptions towards their learning and teaching of mathematics

Although a positive shift was noted in this study, there was a difference with regard to the students' attitudes to learning of mathematics and that of teaching mathematics. Only fifty percent of the students interviewed conceded that they felt confident enough to teach mathematics lessons in their first year of practice teaching even though their academic results and attitude towards the subject had changed. Many of them remarked that they were not adequately prepared to manage mathematical queries that might arise in the classroom. Hopefully, these first year students' confidence levels will grow by the time they graduate and enter the classroom. This important finding highlights an area that requires further exploration as it will be useful to understand why such inadequacies prevailed.

Notwithstanding the lack of confidence to teach mathematics, the findings reveal that the teaching strategies used in the MIP were adopted by the students in that they recognized these strategies as techniques that could be used in their own teaching of mathematics during practice teaching and later as professional teachers. This finding demonstrated that the MIP had an impact on students' perceptions of their mathematics teaching.

\section{Conclusion}

Using the AT framework as a lens for analysis and understanding, the investigation was able to dissect the MIP across all the components of its activity. The results of this study provided therefore a more holistic understanding of how the MIP influenced a change in the students' perceptions of learning and teaching mathematics. Overall, the study provided some insight into how interventions can work in increasing the confidence of at-risk students in a South African context. In particular, the study highlighted that it is possible to ensure that newly qualified teachers return to schools with positive perceptions of mathematics. Although the study has not been able to provide evidence of how these students will actually perform as teachers of mathematics, it does however set the stage for further investigation in this regard. 
Activity Theory as a lens to examine pre-service teachers' perceptions of learning and teaching of Mathematics within an intervention programme

Finally, the findings of this study provided insight as to how the problems related to mathematics teaching and learning, can be overcome. Importantly, it should be noted that the MIP, like various other intervention programmes characterising the South African higher education landscape, are symptoms of the deeper consequences of apartheid education and a fledgling democracy. The injection of better equipped mathematics teachers into the school system, while important, needs to be located within an overhaul of the school system as a whole so that other problems such as lack of physical infrastructure, large class sizes, and paucity of teaching and learning resources are simultaneously addressed.

\section{References}

Arends, F. (2008). Understanding Teacher Demand in South Africa. Teacher Education Series. Cape Town: HSRC Press.

Cooper, R. (2007). An investigation into constructivism within an outcomes based curriculum, Issues in Educational Research, 17(1), 15-39.

Daydov, V.V. (1999). The content and unsolved problems of activity theory. In Y. Engeström, R. Miettinen \& R.L. Punmäki (Eds). Perspectives on activity theory. (pp. 39-52) Cambridge, England: Cambridge University Press.

Eaton, P.T., \& Kidd, S. (2005). Self-conceptualised perceptions of attitude and ability amongst student teachers. Proceedings of the 4th Congress of the European Society for Research in Mathematics Education, Sant Feliu de Guixols, Spain, 17-21 February 2005 (pp.174-182).

Engeström, Y. (1987). Learning by expansion: An activity theoretical approach to developmental research. Helsinki: Orienta-Knosultit Oy.

Hardman, J. (2005). Activity Theory as a framework for understanding teacher's perceptions of computer usage at a primary school level in South Africa. South African Journal of Education, 25(4), 258-265.

Howells, K. (2003). The first year experience: starting with the student. The 7th Pacific Rim- First Year in Higher Education Conference. Retrieved from http://www.fyhe.com.au/past_papers/papers03/ Refereed\%20Papers/Strategies\%20\%26\%20Innovations/Howells_ab.htm

Jansen, J.D. (1998). Curriculum reform in South Africa: A critical analysis of Outcomes-based Education. Cambridge Journal of Education, 28(3), 1-9.

Kukla, A. (2000). Social Constructivism and the Philosophy of Science. New York: Routledge.

Kuutti, K. (1996). Activity theory as a potential framework for human-computer interaction research. In B. Nardi (Ed.), Context and consciousness: activity theory and human-computer interaction. (pp. 17-44). Cambridge, Massachusetts: MIT press.

Leont'ev, A.N. (1978). Activity, consciousness and personality. Englewood Cliffs, New Jersey: PrenticeHall.

Maxwell, M. (1997). Improving Students Learning Skills. Clearwater, Florida: H and H Publishers.

Nurmuliani, N., Zowghi, D., \& Williams, S. P. (2004). Using card sorting technique to classify requirements change. Proceedings of the $12^{\text {th }}$ IEEE International Engineering Conference, 6(11), $240-248$.

Reddy, V. (2006). Mathematics and science achievement at South African schools in TIMSS 2003. Cape Town: HSRC Press.

Roth, W. (2004). Activity theory and education: An introduction. Mind, Culture and Activity. 11 (1), 1-8. 
Russel, D.R. (2002). Looking beyond the interface: Activity theory and distributed learning. In M. R. Lea \& K. Nicoll (Eds.), Distributed Learning: social and cultural approaches to practice. (pp. 64-82) London: Routledge Falmer.

Scott, I., Yeld, N., \& Hendry, J. (2007). A case for improving teaching and learning in South African higher education. Pretoria: Council on Higher Education.

Spady, W. (1994). Outcome-based education: critical issues and answers. Arlington, VA: American Association of School Administrators.

Vygotsky, L.S. (1978). Mind in society, The development of higher psychological processes. Cambridge, Massachusetts: Harvard University Press.

Vygotsky, L.S. (1986). Thought and Language. (rev. ed.). Cambridge, MA: MIT Press.

Van Meter, P., \& Stevens, R. J. (2000). The Role of Theory in the Study of Peer Collaboration. The Journal of Experimental Education, 69(1), 113-127.

Wertsch, J.V. (1997), Mind as action. Oxford: Oxford University Press.

Wiersma, W., \& Jurs, S. G. (2005). Research methods in education: an introduction. ( $8^{\text {th }}$ ed.) New York: Allen and Bacon. 